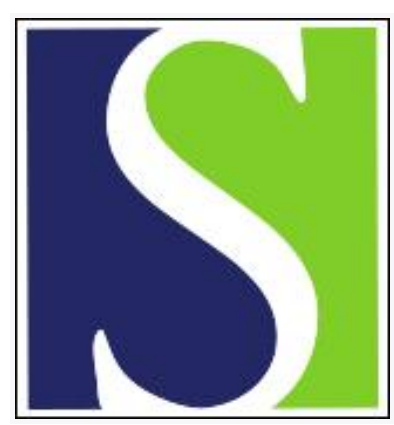

Scand J Work Environ Health 1997;23(6):450-457

https://doi.org/10.5271/sjweh.268

Issue date: Dec 1997

Psychosocial correlates of harassment, threats and fear of violence in the workplace

by Cole LL, Grubb PL, Sauter SL, Swanson NG, Lawless P

The following article refers to this text: $2001 ; 27(6): 361-364$

Key terms: aggression; hostility; job stress; work climate; workplace violence

This article in PubMed: www.ncbi.nlm.nih.gov/pubmed/9476809

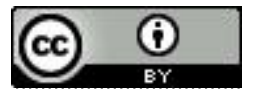




\title{
Psychosocial correlates of harassment, threats and fear of violence in the workplace
}

\author{
by Libby L Cole, PhD, ${ }^{1}$ Paula L Grubb PhD, ${ }^{\prime}$ Steven L Sauter, PhD, ${ }^{1}$ Naomi G Swanson, PhD, ${ }^{1}$ \\ Peggy Lawless ${ }^{2}$
}

\begin{abstract}
Cole LL, Grubb PL, Sauter SL, Swanson NG, Lawless P. Psychosocial correlates of harassment, threats and fear of violence in the workplace. Scand J Work Environ Health 1997;23(6):450-7.

Objectives The purpose of this study was to investigate work climate factors and structural job aspects as predictors of workplace violence, with particular attention to the relative influence of both sets of factors.

Methods Telephone survey data collected by a large midwestern insurance company were analyzed. Interviewers asked 598 full-time workers about their work climate, structural job aspects, and subject and workplace demographics, all of which were used as predictor variables in regression analyses. The participants were also asked about incidents of threats, harassment, physical attacks, and fear of becoming a victim of workplace violence, all of which were used as outcome measures.

Results Separate logistic regressions were carried out for each of the outcome measures. The study identified a variety of factors which appear to place workers at risk of nonfatal occupational violence. Work climate variables, such as co-worker support and work group harmony, were predictive of threats, harassment, and fear of becoming a victim of violence. Structural aspects of the job, such as work schedule, were also significant in predicting threats and fear of becoming a victim of violence, but they were not predictive of harassment.

Conclusions This is the first study which suggests that both work climate and structural aspects of work may be important in promoting workplace violence. This finding suggests that intervention strategies should consider organizational and climate issues in addition to basic security measures.
\end{abstract}

Key terms aggression, hostility, job stress, work climate, workplace violence.

Violence and aggressive or abusive behavior is an increasing concern in today's workplace. Data from the National Institute for Occupational Safety and Health (NIOSH) rank homicide as the leading cause of workplace death for women, and the second leading cause of death at work for all workers (1). According to NIOSH, approximately 7600 workplace murders occurred in the period $1980-1989$ (2). Furthermore, according to Bachman (3), approximately 1 million Americans are victims of robbery or assault each year while on the job. Looking even more broadly at this problem, a recent study by Northwestern National Life Insurance suggests that 25\% of full-time American workers may be victims of workplace violence when the definition is expanded to include threats and harassment, in addition to physical attack (4).
The effects of workplace violence seem to be farreaching, including reduced productivity and morale throughout the entire organization and increased dissatisfaction, absenteeism and turnover intention (4-8). Studies also indicate that victims of violence report more psychological complaints (eg, anxiety, depression, sleeping disorders, feelings of desperation and helplessness, tension, and nervousness) and symptoms reminiscent of posttraumatic stress disorder (9), experience more job burnout, and have more physical symptoms than those who are not victimized $(4,10,11)$. According to the Bureau of Labor Statistics, attack victims commonly require an average of 5 days away from work to recuperate (12).

Historically, workplace violence has been narrowly defined to include only physical assault or homicide that

1 National Institute for Occupational Safety and Health, Division of Biomedical and Behavioral Sciences, Applied Psychology and Ergonomics Branch, Cincinnati, Ohio, United States.

2 Northwestern National Life, Minneapolis, Minnesota, United States.

Reprint requests to: Dr Paula L Grubb, National Institute for Occupational Safety and Health, Division of Biomedical and Behavioral Sciences, Applied Psychology and Ergonomics Branch, 4676 Columbia Parkway, Mail Stop C-24, Cincinnati, OH 45226, USA. [e-mail: PLG4@CDC.GOV] 
occurs at the workplace and that is associated with work activities $(6,13)$. Some studies have counted only physical attacks that result in at least 1 day away from work to recuperate $(12,13)$. Recently, some researchers have broadened the definition of occupational violence to include forms of aggression such as verbal threats, abuse, harassment, any assault or threat that produces psychological harm $(4,6,14,15)$, personal and motor vehicle theft (3), and self-directed violence (eg, suicide) (6).

While a substantial research effort has been directed toward fatal assault in the workplace, nonfatal violence has only recently become a focus of study. Although the knowledge base to date is limited, it suggests notable distinctions between fatal and nonfatal violence. Data indicate that most homicides at work are committed by strangers (12), whereas a considerable proportion of nonfatal workplace violence may be perpetrated by co-workers and supervisors ( $27 \%$ of assaults, $37 \%$ of threats, and $86 \%$ of all harassment) (4).

Preliminary data also suggest differences in motive and risk factors. Robbery has been identified as the motive in a majority of workplace homicides (12), and structural job conditions, which may signal opportunity for the perpetrator, have been found to be associated with the risk of workplace homicide. These conditions include working alone or in small numbers, working late at night, working in high-crime and unsecured areas, exchanging money with the public, guarding valuable property or possessions, and providing goods or services to the public $(5,15-20)$. Much less is known about motive and risk factors for nonfatal workplace violence, but results of the few studies to date indicate that the psychosocial environment may play an etiologic role. Some studies suggest associations between nonfatal aggression or hostility at work and job-related stress and frustration, role ambiguity and conflict, work load, situational constraints, lack of supervisor support, and lack of open communication and cooperation between co-workers (4, $11,21-25)$. Other research $(26,9)$ suggests that a combination of workplace factors (eg, employees' perceived workplace justice, feelings of job insecurity and job competition) and personal factors (eg, past history of aggression, self-esteem) may predict workplace violence.

The aim of the current project was to learn more about the prevalence rates and risk factors for forms of nonfatal workplace violence. A particular interest was to examine the role and strength of workplace psychosocial factors in predicting violence, in addition to examining the influence of structural factors (eg, work schedule, money handling) which have captured most of the attention thus far in the study of workplace violence. For the purpose of this study, we adopted a broad definition of nonfatal violence which, consistent with the definitions of the Center for Mental Health Services (6), the Health Service Advisory Committee (14), and Thomas (15), includes threats and harassment, as well as physical assault.

The data for this study came from a telephone survey (4), commissioned by Northwestern National Life Insurance, eliciting information on work conditions and experience with workplace violence among 600 workers. The survey was designed by the insurance company in conjunction with a panel with expertise in stress and violence, including two of us. Logistic regression methods were then used to examine the relationship between a variety of job characteristics and measures of violence.

\section{Subjects and methods}

\section{Subjects}

Six-hundred civilian workers, 19 years of age and older, took part in this study in the United States. Participation criteria were established to identify respondents who were representative of the national population of fulltime workers. These criteria included having worked for only 1 employer for at least 8 of the previous 12 months and having worked at least 35 hours per week during those months. Business owners and the self-employed were excluded from the study. Data from 2 participants were excluded due to missing values and therefore the final number of participants was 598 .

The survey participants were selected through a national random sample of telephone numbers and contacted by phone. Of the 3399 people who were contacted, 1149 did not meet the selection criteria, 194 did not participate due to a language barrier, 1418 refused to begin the survey, 38 were eligible but terminated participation, and 600 were eligible and participated. According to the survey research firm that conducted the telephone interviews, these frequencies are typical for the large-scale telephone surveys they conduct (NK Friedrichs, personal communication, 13 November 1994). If it is assumed that all of those who refused to begin the survey $(\mathrm{N}=1418)$ were in fact eligible, the response rate for the study would be $29 \%[600 /(1418+38+600)]$. However, based on the percentage of people who met study criteria $[(600+38) /(1149+38+600)=36 \%]$, we can estimate that, of the 1418 who refused to begin, approximately $510(0.36 \times 1418)$ would have met eligibility criteria. This estimation would reduce the denominator for calculating participation rate from 2056 to 1148 (ie, $510+38+600$ ) and result in a $52 \%$ participation rate (600/1148).

To determine whether this sample was representative of the employed civilian population as a whole in the United States, respondent profiles were compared in table 1 with national data collected by the Bureau of the 
Census $(27,28)$. As shown in table 1 , profile characteristics for the study sample, including gender, census region, age, race, and union affiliation correspond closely with national figures (although managers and professionals are somewhat overrepresented, and business and personal services are somewhat underrepresented in the study sample) and therefore suggest that the sample is reasonably representative of full-time civilian employees in the United States.

\section{Procedure}

The survey was conducted by a professional telephone survey research firm between 13 July and 27 July 1993. During the initial contact with potential participants, the interviewers described the survey as a "national study on job stress", and asked respondents their age and about their employment history to determine participation eligibility. If respondents met the selection criteria, they were asked about their place of employment, the incidence of violence in their workplace, and the conditions of their work.

Table 1. Demographic comparison of study participants with employed civilians of the United States.

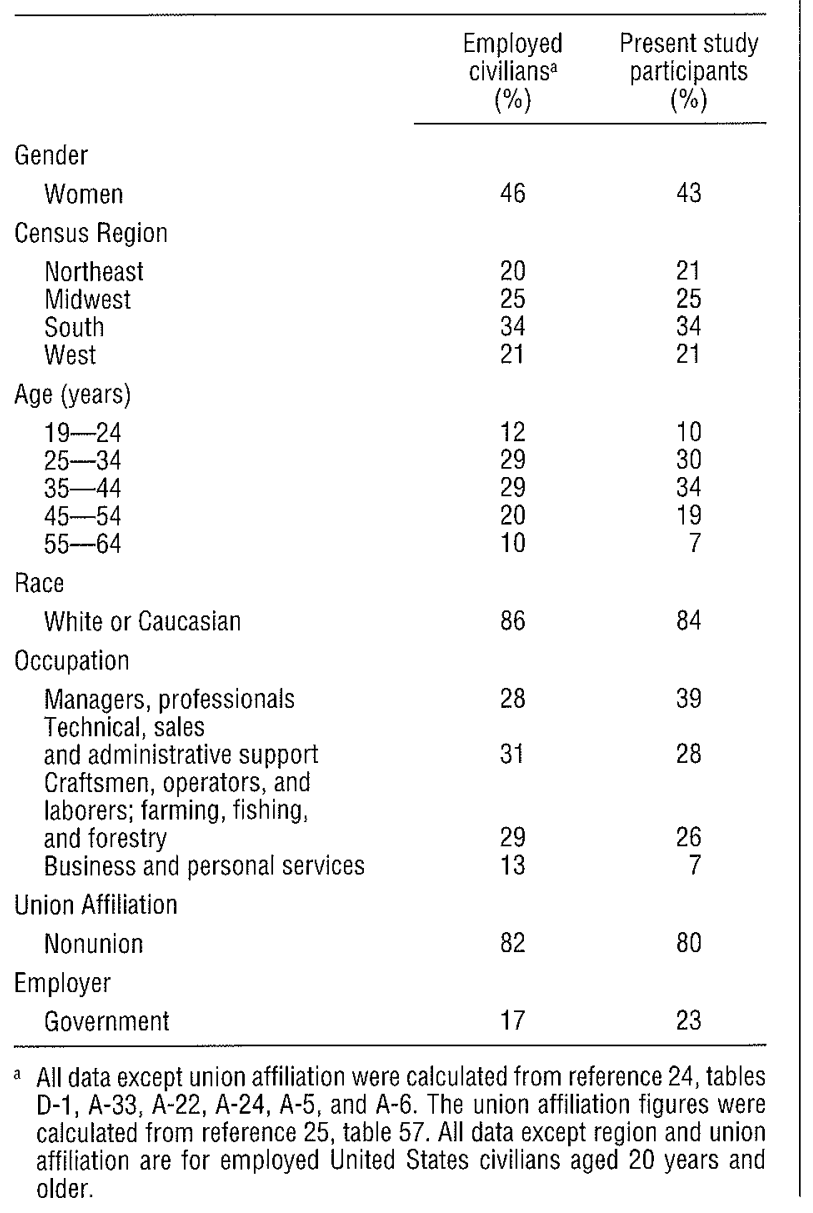

Independent variables. The respondents were asked about the following variables, which were used as predictors of the various measures of violence described below: (i) work climate variables (work group harmony, supervisor support, co-worker support, work meaningfulness, and job control), (ii) structural aspects of the job (work schedule, money handling, and dealing with the public), (iii) job uncertainty factors (layoffs or firing in the past 12 months; layoff worry), (iv) respondent demographics (gender and age), (v) workplace demographics (workplace location, number of employees, and employer), and (vi) professional or career status variables (occupation, supervisory status, and union membership). The response categories for several variables were recoded from their original format to binary form.

Dependent variables. The respondents were also asked about incidents of violence in their workplace, which were of 2 types - incidents occurring to the respondent and incidents occurring to others in the respondent's workplace. The dependent variables were (i) respondent's fear of becoming a victim of violence while on the job in the past 12 months, (ii) harassment directed at the respondent while at work in the past 12 months, (iii) threats against the respondent while at work in the past 5 years, (iv) threats against others in the respondent's workplace in the past 12 months, and (v) physical attacks against others in the respondent's workplace in the past 12 months. The time frame for threats against the respondent was the past 5 years rather than the past 12 months due to the low frequency of threats in the previous 12 months $(7 \%)$. Physical attacks against the respondent were not examined in the present study due to the low frequency of these events in the preceding 12 -month period $(3 \%)$ or in the past 5 years $(7 \%)$.

All outcome variable responses were binary (yes or no) except for fear of becoming a victim of violence, which was dichotomized from a 4-point scale $(1=$ very often, 2 = somewhat often, $3=$ not very often, $4=$ never $)$ into "often fear violence" (combined categories of "very often" and "somewhat often") and "do not often fear violence" (combined categories of "not very often" and "never").

\section{Results}

Sixty-two respondents $(10 \%)$ reported being afraid of becoming a victim of violence at work in the last 12 months. One-hundred and twelve respondents (19\%) reported having been harassed in the past 12 months, and 80 participants $(13 \%)$ reported having been threatened in the past 5 years while on the job. The corresponding value for threats to others was slightly higher $(23 \%)$. In 
addition, 82 participants (14\%) reported that other persons in their workplace were physically attacked on the job in the last 12 months.

\section{Predictors of violence}

Separate stepwise logistic regressions were carried out for each of the violence outcomes. These analyses were performed in 2 stages for the outcome variables reflecting violence to oneself (fear of violence, harassment, and personal threat). In the first stage, separate models were developed for each class of predictor variable. For example, for the fear of violence outcome measure, separate logistic models were developed for the work climate variables, work structure variables, job uncertainty variables, respondent demographic variables, workplace demographic variables, and professional status variables. A similar procedure was also followed for the harassment and personal threat outcomes. In stage 2 , the variables significant in each of the stage 1 models were combined together in a final regression analysis for each outcome (fear of violence, harassment, and personal threat).

For the outcome measures involving "others" in the respondent's workplace (ie, threats against anyone in the respondent's workplace in the past 12 months and physical attacks against anyone in the respondent's workplace in the past 12 months) workplace demographic factors and layoffs or firings in the last 12 months were the only predictors entered into the logistic regressions. The remaining predictors were not used because they dealt with the respondent's personal experience and activities (eg, work schedule, money handling, age, etc) which could not reliably be generalized from the respondent to the victimized worker. Since these analyses involved a reduced set of predictors, preliminary models were not developed for these 2 dependent measures.

The results of the stage 1 analyses are summarized in table 2. For all practical purposes, the outcome measures included in this table (fear of violence, harassment, and personal threat) can be considered independent, with correlations ( $r$ ) ranging from $r=0.08$ to $r=0.25$. Among all of the violence outcome measures, only 2 of the intercorrelations exceeded $r=0.25$. Personal threat in the past 5 years was correlated with threat to anyone in the organization (in the last year) at $r=0.38$, and threat to anyone was correlated with attack on anyone in the last year at $\mathrm{r}=0.43$.

Table 2. Summary of the stage 1 logistic regressions. [.. = no odds ratio computed because variable did not enter significantly into the regression model, $N S=$ not significant $(P>0.05), 0 R=$ odds ratio $]$

\begin{tabular}{|c|c|c|c|c|c|c|}
\hline \multirow[t]{2}{*}{ Predictor classes } & \multicolumn{2}{|c|}{ Fear of violence } & \multicolumn{2}{|c|}{ Harassment } & \multicolumn{2}{|c|}{ Personal threats } \\
\hline & OR & P-value & $\mathrm{OR}$ & P-value & OR & P-value \\
\hline \multicolumn{7}{|l|}{ Work climate } \\
\hline $\begin{array}{l}\text { Work group } \\
\text { harmony (low) } \\
\text { Supervisor }\end{array}$ & .. & NS & 2.13 & $<0.01$ & 1.98 & $<0.02$ \\
\hline $\begin{array}{l}\text { support (low) } \\
\text { Co-worker }\end{array}$ & ." & NS & 1.75 & $<0.05$ & 2.00 & $<0.02$ \\
\hline $\begin{array}{l}\text { support (low) } \\
\text { Work }\end{array}$ & 3.55 & $<0.001$ & 1.82 & $<0.05$ &. & NS \\
\hline $\begin{array}{l}\text { meaningfulness } \\
\text { Job control }\end{array}$ & .. & $\begin{array}{l}\text { NS } \\
\text { NS }\end{array}$ & $\begin{array}{l}. . \\
. .\end{array}$ & $\begin{array}{l}\text { NS } \\
\text { NS }\end{array}$ & $\begin{array}{l}. . \\
. .\end{array}$ & $\begin{array}{l}\text { NS } \\
\text { NS }\end{array}$ \\
\hline \multicolumn{7}{|l|}{ Work structure } \\
\hline $\begin{array}{l}\text { Schedule (1700-0800) } \\
\text { Money handling } \\
\text { Deal with public }\end{array}$ & $\begin{array}{l}2.76 \\
\ddot{.} \\
2.91\end{array}$ & $\begin{array}{l}<0.01 \\
\text { NS } \\
<0.001\end{array}$ & $\begin{array}{l}. \ddot{ } \\
.\end{array}$ & $\begin{array}{l}\text { NS } \\
\text { NS } \\
\text { NS }\end{array}$ & $\begin{array}{l}2.10 \\
1.98 \\
. .\end{array}$ & $\begin{array}{l}<0.05 \\
<0.02 \\
\text { NS }\end{array}$ \\
\hline \multicolumn{7}{|l|}{ Job uncertainty } \\
\hline $\begin{array}{l}\text { Layoffs or firings } \\
\text { Layoff worry }\end{array}$ & $3 . \ddot{25}$ & $\begin{array}{c}N S \\
<0.01\end{array}$ & $\begin{array}{l}1.86 \\
2.54\end{array}$ & $\begin{array}{l}<0.01 \\
<0.05\end{array}$ & $\begin{array}{l}. . \\
. .\end{array}$ & $\begin{array}{l}\text { NS } \\
\text { NS }\end{array}$ \\
\hline \multicolumn{7}{|l|}{ Respondent demographics } \\
\hline $\begin{array}{l}\text { Age (19-44) } \\
\text { Gender (female) }\end{array}$ & $\begin{array}{l}. . \\
. .\end{array}$ & $\begin{array}{l}\text { NS } \\
\text { NS }\end{array}$ & $\begin{array}{l}1.95 \\
1.71\end{array}$ & $\begin{array}{l}<0.02 \\
<0.02\end{array}$ & .. & $\begin{array}{l}\text { NS } \\
\text { NS }\end{array}$ \\
\hline \multicolumn{7}{|l|}{ Workplace demographics } \\
\hline $\begin{array}{l}\text { Location (central city) } \\
\text { Number of } \\
\text { employees ( } \geq 250 \text { ) } \\
\text { Type of employer } \\
\text { (nonprofit or government) }\end{array}$ & $\begin{array}{c}1.72 \\
. . \\
1.73\end{array}$ & $\begin{aligned}< & 0.05 \\
& \text { NS } \\
< & 0.05\end{aligned}$ & $\begin{array}{l}. . \\
. . \\
. .\end{array}$ & $\begin{array}{l}\text { NS } \\
\text { NS } \\
\text { NS }\end{array}$ & $\begin{array}{l}. . \\
. . \\
. .\end{array}$ & $\begin{array}{l}\text { NS } \\
\text { NS } \\
\text { NS }\end{array}$ \\
\hline \multicolumn{7}{|l|}{ Professional status } \\
\hline $\begin{array}{l}\text { Occupation } \\
\text { (professional) } \\
\text { Supervisor } \\
\text { Union member }\end{array}$ & & $\begin{array}{l}\text { NS } \\
\text { NS } \\
\text { NS }\end{array}$ & $\begin{array}{l}. . \\
. . \\
. .\end{array}$ & $\begin{array}{l}\text { NS } \\
\text { NS } \\
\text { NS }\end{array}$ & $\begin{array}{c}. \ddot{8} \\
\ddot{.}\end{array}$ & $\begin{array}{l}\text { NS } \\
<0.02 \\
\text { NS }\end{array}$ \\
\hline
\end{tabular}


Table 2 shows that variables within every predictor class were significant predictors of at least 1 of the outcome measures. Of special interest, several of the variables which could denote stressful work conditions (eg, low work group harmony, low supervisor or co-worker support, and layoff worry) were predictive of multiple violence outcomes.

Tables 3 and 4 provide the results of the stage 2 analyses in which separate stepwise logistic regressions were conducted for each outcome measure, combining all significant predictors of that measure from the stage 1 analyses. These tables contain the significant odds ratios for the predictor measures, along with the probability values and $95 \%$ confidence intervals for each odds ratio. Table 3 contains this information for incidents experienced directly by the respondents, while table 4 summarizes the results of the logistic regressions for incidents involving others in the respondents' workplace.

Fear of violence. The stepwise logistic regression for fear of becoming a victim of violence at work included the following variables as predictors: co-worker support, work schedule, dealing with the public, layoff worry, location of worksite, and profit versus nonprofit employer. As shown in table 3 , all but the employer variable remained significant in predicting this measure. Fear of violence was more common for workers reporting reduced co-worker support, increased layoff worry, night work, and frequent dealings with the public. Considering these variables, it is of some interest that the odds ratios were the most elevated for factors suggestive of stress at work (ie, higher levels of layoff worry and low co-worker support) followed in decreasing order by dealing with the public and nightwork schedule.

Harassment. Predictor variables for the harassment analysis included work group harmony, supervisor support, co-worker support, layoff worry, layoffs or firings in the past 12 months, age, and gender variables. Table 3 shows that, in the final model, all but layoff worry and supervisor support retained their significance. Effects for the predictor variables were similar in direction and magnitude to that seen in the stage 1 analyses. Harassment was more prevalent when workers reported low levels of work

Table 3. Summary of the final logistic regression model for fear of being a victim of violence, harassment, and personal threats. $(\cdot \cdot=$ variables not entered into the final regression model for the given dependent variable, $\mathrm{OR}=$ odds ratio, $95 \% \mathrm{Cl}=95 \%$ confidence interval)

\begin{tabular}{|c|c|c|c|c|c|c|c|c|c|}
\hline \multirow[t]{2}{*}{ Predictor classes } & \multicolumn{3}{|c|}{ Fear of violence } & \multicolumn{3}{|c|}{ Harassment } & \multicolumn{3}{|c|}{ Personal threats } \\
\hline & $0 R$ & $95 \% \mathrm{Cl}$ & P-value & $\mathrm{OR}$ & $95 \% \mathrm{Cl}$ & P-value & $\mathrm{OR}$ & $95 \% \mathrm{Cl}$ & P-value \\
\hline \multicolumn{10}{|l|}{ Work climate } \\
\hline $\begin{array}{l}\text { Work group } \\
\text { harmony (low) }\end{array}$ & ." & .. & .. & 2.51 & $1.52-4.13$ & 0.0003 & 1.99 & $1.09-3.61$ & 0.03 \\
\hline $\begin{array}{l}\text { support (low) } \\
\text { Co-worker }\end{array}$ &. & .. & .. & .. & .. &. & 2.20 & $1.23-3.95$ & 0.01 \\
\hline support (low) & 5.18 & $2.69-9.90$ & 0.0001 & 2.04 & $11.16-3.62$ & 0.02 & ." & .. &.$\cdot$ \\
\hline \multicolumn{10}{|l|}{ Work structure } \\
\hline $\begin{array}{l}\text { Schedule }(1700-0800) \\
\text { Money handling } \\
\text { Deal with public }\end{array}$ & $\begin{array}{c}3.51 \\
. . \\
4.58\end{array}$ & $\begin{array}{c}1.66-7.46 \\
\ldots \\
2.27-9.26\end{array}$ & $\begin{array}{c}0.001 \\
. . \\
0.0001\end{array}$ & $\begin{array}{l}. . \\
. . \\
. .\end{array}$ & $\begin{array}{l}. . \\
. . \\
. .\end{array}$ & $\begin{array}{l}. . \\
. . \\
. .\end{array}$ & 1.85 & $1.05-3.24$ & $\begin{array}{l}. . \\
0.04 \\
. .\end{array}$ \\
\hline \multicolumn{10}{|l|}{ Job uncertainty } \\
\hline $\begin{array}{l}\text { Layoff worry } \\
\text { Layoffs }\end{array}$ & $\begin{array}{l}6.83 \\
. .\end{array}$ & $\begin{array}{c}2.44-19.11 \\
.\end{array}$ & $\begin{array}{c}0.0003 \\
. .\end{array}$ & $\begin{array}{c}. . \\
1.97\end{array}$ & $1.26-3.09$ & 0.01 & $\begin{array}{l}. . \\
. .\end{array}$ & $\begin{array}{l}. . \\
. .\end{array}$ & $\begin{array}{l}. . \\
. .\end{array}$ \\
\hline \multicolumn{10}{|l|}{ Respondent demographics } \\
\hline $\begin{array}{l}\text { Age ( } 19-44 \text { years) } \\
\text { Gender (female) }\end{array}$ & $\begin{array}{l}. . \\
. .\end{array}$ & . & $\begin{array}{l}. . \\
. "\end{array}$ & $\begin{array}{l}2.13 \\
1.81\end{array}$ & $\begin{array}{l}1.19-3.81 \\
1.15-2.82\end{array}$ & $\begin{array}{l}0.02 \\
0.01\end{array}$ & $\begin{array}{l}. . \\
. .\end{array}$ & $\begin{array}{l}. \cdot \\
.\end{array}$ & $\begin{array}{l}. . \\
. .\end{array}$ \\
\hline \multicolumn{10}{|l|}{ Professional status } \\
\hline Supervisor & .. & .. & .. & .. & .. & .. & 1.86 & $1.09-3.16$ & 0.03 \\
\hline
\end{tabular}

Table 4. Summary of the final logistic regression model for physical attacks and threats against anyone in the respondent's workplace. $(. .=$ variables not entered into the final regression model for the given dependent variable, $\mathrm{OR}=$ odds ratio, $95 \% \mathrm{Cl}=95 \%$ confidence interval)

\begin{tabular}{|c|c|c|c|c|c|c|}
\hline \multirow[t]{2}{*}{ Predictor classes } & \multicolumn{3}{|c|}{ Physical attacks } & \multicolumn{3}{|c|}{ Threats (others) } \\
\hline & $\mathrm{OR}$ & $95 \% \mathrm{Cl}$ & P-value & $\mathrm{OR}$ & $95 \% \mathrm{Cl}$ & P-value \\
\hline \multicolumn{7}{|l|}{ Workplace demographics } \\
\hline Location (central city) & 1.80 & $1.11-2.94$ & 0.02 & .. & .. & ." \\
\hline Number of employees $(\geq 250)$ & 2.46 & $1.51-4.02$ & 0.0003 & .. & .. & .. \\
\hline Employer (nonprofit or government) & 2.12 & $1.31-3.46$ & 0.01 & 1.99 & $1.34-2.96$ & 0.001 \\
\hline
\end{tabular}


group harmony and co-worker support and increased layoffs in the organization. Women and younger workers were more likely to report being harassed. Again, the magnitude of the odds ratios were somewhat higher for the stress-related factors, although in this and all the remaining analyses the overall size of the odds ratios for all the variables was considerably reduced in comparison with the odds ratios for predicting fear of violence.

Threats (against respondent). The variables examined in the final model for threats against the respondent included work group harmony, supervisor support, schedule, money handling, and supervisory status. As shown in table 3, all but the schedule variable survived the analysis, and the direction and magnitude of the effects for these variables were the same as in the stage 1 analyses. Specifically, threat was more common for workers reporting low work group harmony and supervisor support, handling money at work, and being a supervisor.

Threats and physical attacks (against anyone in the workplace). For threats against anyone in the respondent's workplace, location of worksite, number of employees, actual layoffs or firings, and type of employer were entered as predictors. As shown in table 4, only type of employer was predictive of threats against others in the respondent's workplace, with increased threats for workers in nonprofit or government organizations.

In contrast, all of the workplace demographic variables were predictive of physical attacks in the last 12 months, with increased attacks for workplaces in central city locations, for those with employment exceeding 250 workers, and for nonprofit or government organizations (table 4).

\section{Discussion}

Our study examined the prevalence of various forms of nonfatal violence in the workplace, and it is the first investigation to examine concurrently the association of both workplace psychosocial factors and more structural aspects of the job with nonfatal occupational violence.

The analyses found that both classes of variables were important predictors of multiple measures of workplace violence. Stressors, such as reduced co-worker and supervisory support, lack of work group harmony, and layoff worry were associated with violence outcomes in all the regression models in which they were included as predictors (ie, fear of violence, harassment, and personal threats). Similarly, structural variables, including work schedule, dealing with the public, layoffs within the past year, and money handling, were found to be important predictors of fear of violence, harassment, personal threats, and physical attacks. Although both classes of variables were predictive of violence, it is of interest that the odds ratios for psychosocial factors tended to be somewhat higher than the odds ratios for the structural variables in cases in which it was possible to assess the relative influence of both sets of variables.

These results support the finding of a handful of studies which have also linked stressful work environments with nonfatal workplace aggression. For example, Vartia (11) found that nonfatal violence and aggression among co-workers was more common in workplaces with a strained and competitive atmosphere, poor employee-management relations, and low supervisor and co-worker support. Similarly, the Center for Mental Health Services (6) has reported that violence is more likely in organizations with poor managerial practices and poor communication between co-workers and supervisors, and studies by Spector \& Chen $(21,23)$ reveal an increase in aggression among employees who experience job frustration, role ambiguity and conflict, and situational constraints.

Cox \& Leather (29) have reviewed the extensive literature on psychological theories of aggression and provide a framework for understanding the effects of psychosocial factors on violence in these studies. According to their analysis, aggression can be understood as a reaction to noxious events [ie, the frustration-aggression hypothesis (30)] or as a means of coping or exercising control $(31-33)$. Within this theoretical framework, it is plausible that an unsupportive work environment (ie, low supervisor or co-worker support) might provoke violence as a reaction to an aversive situation in the workplace or possibly promote aggressive behavior as a method of securing the support or resources needed to work more effectively.

Current results also correspond with traditional research on workplace violence demonstrating an association of more structural aspects of the job with occupational violence. For example, working alone, working late at night, exchanging money with the public, providing goods or services to the public, and working in community settings (eg, taxicab drivers and police) have been associated with the occurrence of homicide and violent physical attacks $(5,12,15-20,34)$.

It is plausible that the influence of workplace psychosocial stressors on violence is contingent on the source of the violence. For example, it could be argued that there should be only minimal or no influence of the workplace psychosocial environment on violence perpetrated by persons outside the organization. ${ }^{3}$ To examine this possi-

3 However, it could be speculated that an adverse psychosocial environment at work might increase the potential for violence by promoting stressful interactions between employees and customers. 
bility, analyses were conducted to determine the association between each psychosocial variable and the outcome measures of harassment and threats. Only the associations with harassment and threats were examined because information regarding the origin of the perpetrator (inside versus outside the organization) was not available for the other outcome measures. Results showed that the association between the job climate variables and the occurrence of threats or harassment perpetrated by those inside the organization was significant in all but 1 case $(\mathrm{P}<0.05)$, whereas none of the job climate variables were associated with violence perpetrated by persons from outside the organization. These results strengthen the suggested association between the workplace psychosocial environment and violence in two ways. First, the pattern suggests that the results of the present regression analyses underestimate the actual strength of association between workplace psychosocial factors and violence potential because the sample for the regression analyses did not distinguish between internal and external perpetration of violence. That is, the reduced association between workplace psychosocial factors and outsider-perpetrated violence would tend to depress the correlation between psychosocial factors and insider-perpetrated violence when the two are combined in the same analysis. In addition, confidence in cross-sectional studies is often eroded because they cannot ascertain the direction of causation. It might be argued, for example, that workplace violence leads to more negative assessments of the psychosocial environment and not the reverse. Were this the case in our study, however, significant associations between psychosocial factors and outsider-perpetrated violence would have been anticipated. Further, to the issue of reverse causation, it is difficult to imagine how workplace violence could influence a factor such as "layoff worry".

A limitation of our study is the reduced response rate, which raises the possibility that the observed prevalence of violence outcomes may be inflated for some reason. For example, workers experiencing stress might have been more likely to consent to participate in the study. Under these circumstances the violence prevalence would be inflated given the association we observed between stress and violence. However, it is unlikely that this sampling issue would bias the observed relationship between stress and violence.

In summary, the current results add to the growing, but still tenuous, body of data suggesting an influence of psychosocial factors on workplace violence. Further research is needed to confirm this relationship. In particular, studies are needed to extend the present type of analyses to actual physical assault by workers and outsiders separately, although the infrequent occurrence of workplace assaults may stand as an important obstacle to such research. Notwithstanding these research needs, the growing evidence implicating the psychosocial environment as an etiologic factor for workplace violence suggests the importance of closer attention to the design of work systems and workplace culture as part of the organizational response to the prevention of violence at work $(4,29)$.

\section{Acknowledgments}

We would like to thank Northwestern National Life for commissioning this study on workplace violence and for providing us with access to the survey data.

\section{References}

1. Jenkins EL. Workplace homicide: industries and occupations at high risk. In: Harrison R, editor. Violence in the workplace. Philadelphia (PA): Hanley \& Belfus, Inc, 1996:219-25. Occupational medicine state of art reviews.

2. National Institute for Occupational Safety and Health (NIOSH). Fatal injuries to workers in the United States, 1980 1989: a decade of surveillance, national profile. Cincinnati $(\mathrm{OH})$ : US Department of Health and Human Services, Public Health Service, Centers for Disease Control and Prevention, NIOSH, 1993. DHHS (NIOSH) publication no 93-108.

3. Bachman R. Violence and theft in the workplace. Exchange 1994;September:4-5.

4. Northwestern National Life Insurance Company. Fear and violence in the workplace. Minneapolis (MN): Northwestern National Life, 1993.

5. Mantell M. Ticking bombs: defusing violence in the workplace. New York (NY): Irwin Professional Publishing, 1994.

6. Center for Mental Health Services. Forum report: preventing violence in the workplace (February/March). Rockville (MD): Substance Abuse and Mental Health Services Administration, US Department of Health and Human Services, 1994.

7. Occupational Safety \& Health Reporter. Current report: workplace violence. Washington (DC): Bureau of National Affairs, 1994.

8. Stockdale J, Phillips C. Physical attacks and threatening behavior - new survey findings. Occup Health 1989;August: $212-6$.

9. Björkqvist K, Österman K, Hjelt-Bäck M. Aggression among university employees. Aggressive Behav 1994;20:173-84.

10. Raknes B, Einarsen S. Bullying in the health care sector. In: Bast-Petterson R, Bach E, Lindström K, Toomingas A, Kiviranta $\mathbf{J}$, editors. Research on violence, threats, and bullying as health risks among health care personnel. Copenhagen: The Nordic Council of Ministers, 1995:32 -7. TemaNord 583.

11. Vartia M. Bullying at workplaces. In: Bast-Petterson R, Bach E, Lindström K, Toomingas A, Kiviranta J, editors. Research on violence, threats, and bullying as health risks among health care personnel. Copenhagen: The Nordic Council of Ministers, 1995:29-31. TemaNord 583.

12. Bureau of Labor Statistics. Violence in the workplace comes under closer scrutiny. Washington (DC): US Department of Labor, 1994:Summary:94-10. 
13. Hales T, Seligman P, Newman S, Timbrook C. Occupational injuries due to violence. J Occup Med 1988;30:483-7.

14. Health Services Advisory Committee. Violence to staff in the health services. London: Crown, 1987.

15. Thomas J. Occupational violent crime: research on an emerging issue. J Saf Res 1992;23:55 - 62.

16. Davis H. Workplace homicides of Texas males. Am J Public Health 1987;77:1524-7.

17. Jenkins EL, Layne LA, Kisner SM. Homicide in the workplace: the US experience, 1980-1988. Am Assoc Occup Health Nurses J 1992;40:215-8.

18. Kraus J. Homicide while at work: persons, industries, and occupations at high risk. Am J Public Health 1987;77:12859.

19. National Institute for Occupational Safety and Health (NI$\mathrm{OSH})$. Preventing homicide in the workplace. Cincinnati (OH): US Department of Health and Human Services, Public Health Service, Centers for Disease Control and Prevention, NIOSH, 1993. DHHS (NIOSH) publication no 93-109.

20. Poyner B, Warne C. Violence to staff: a basis for assessment and prevention. London: Crown, 1986.

21. Chen PY, Spector PE. Relationships of work stressors with aggression, withdrawal, theft and substance use: an exploratory study. J Occup Organ Psychol 1992;65:177-84.

22. Mangione T, Quinn R. Job satisfaction, counterproductive behavior, and drug use at work. J Appl Psychol 1975;60:114 6.

23. Spector PE. Relationships of organizational frustration with reported behavioral reactions of employees. J Appl Psychol 1975;60:635-7.

24. Leymann H. Mobbing and psychological terror at workplaces.
Violence Victims 1990;5:119-26.

25. Einarsen S, Skogstad A. Bullying at work: epidemiological findings in public and private organizations. Eur J Work Organ Psychol 1996;5:185-201.

26. Barling J. The prediction, psychological experience, and consequences of workplace violence. In: VanderBos GR, Bulatao $E Q$, editors. Violence on the job: Identifying risks and developing solutions. Washington (DC): American Psychological Association, 1996:29—49.

27. US Department of Labor. Employment and earnings (August). Washington (DC): US Government Printing Office, 1993.

28. US Department of Labor. Employment and earnings (January). Washington (DC): US Government Printing Office, 1994.

29. Cox T, Leather P. The prevention of violence at work: application of a cognitive behavioral theory. In: Cooper CL, Robertson IT, editors. New York (NY): Wiley, 1994:9. International Review of Industrial and Organizational Psychology.

30. Dollard J, Doob L, Miller N, Mowrer O, Sear R. Frustration and aggression. New Haven (CT): Yaie University Press, 1939.

31. Bandura A. Aggression: a social learning analysis. New Jersey (NJ): Englewood Cliffs, Prentice-Hall, 1973.

32. Berkowitz L. Aggression: a social psychological analysis. New York (NY): McGraw-Hill, 1962.

33. Berkowitz L. The frustration-aggression hypothesis: An examination and reformation. Psychol Bull 1989;106:59_73.

34. Poyner B. The prevention of violence to staff. J Health Saf 1988;1:19-26.

Received for publication: 4 October 1996 